\title{
Arsenic Induced Changes in Growth and Physiological Responses in Vigna radiata Seedling: Effect of Curcumin Interaction
}

\author{
Hrishikesh Upadhyaya, Soumitra Shome, Deboshri Roy, Mrinal Kanti Bhattacharya \\ Department of Botany and Biotechnology, Karimganj College, Karimganj, India \\ Email: hkupbl au@rediffmail.com
}

Received 30 September 2014; revised 29 October 2014; accepted 15 November 2014

Copyright (C) 2014 by authors and Scientific Research Publishing Inc.

This work is licensed under the Creative Commons Attribution International License (CC BY). http://creativecommons.org/licenses/by/4.0/

c) (i) Open Access

\begin{abstract}
Arsenic is a great hazard to the environment since it is a major source of soil and water contamination leading to phytotoxicity. Arsenic caused reduction in seed germination and growth of plants including mung bean (Vigna radiata) causing loss of crop productivity. This investigation evaluates effect of arsenic toxicity in mung bean with an attempt to ameliorate it by the application of curcumin. Arsenic induced reduction in fresh, dry mass, length of root and shoot and pigment content. The result of the present study suggests that curcumin at lower concentration ameliorates arsenic induced toxicity in Vigna radiata.
\end{abstract}

\section{Keywords}

Arsenic Stress, Curcumin, Vigna radiata

\section{Introduction}

Arsenic (As) contamination in environment, from both anthropogenic and natural sources occurs is a global problem. As is a metalloid having properties of both metals and non-metals, and can undergo different ranges of chemical interactions in plants. Historically, the extensive use of arsenic-based pesticides has led to considerable contamination of domestic and agricultural land, through their use as lawn herbicides, and insecticides for rice plants, cotton, etc. [1]. Arsenic is a non-essential element and, in general, inorganic ones are phytotoxic. Arsenic is toxic to a wide range of organisms, including plants [2]. Studies on arsenic toxicity have shown that plant species not resistant to arsenic suffer considerable stress upon exposure, with symptoms ranging from inhibition of root growth to death [3]-[6].

Exposure of plants to arsenic causes reduction in photosynthetic rate [7], for example: in maize (Zea mays) 
plant, the rate of $\mathrm{CO}_{2}$ fixation in young plants treated with arsenic decreased by $20 \%$ and functional activity of PSII was reduced significantly [8]. The decreased photosynthetic rate under stress condition could be due to both stomatal and mesophyll limitations. The mesophyll factors could be of a different nature, such as disturbances in the chlorophyll, light and biochemical reactions from the Calvin Cycle [7]. In rice seedlings arsenic toxicity causes changes in carbohydrate metabolism leading to the accumulation of soluble sugars by altering enzyme activity. Sucrose synthase possibly plays a positive role in synthesis of sucrose under As-toxicity [9].

Arsenic is known to induce oxidative stress in plants [10], resulting in a range of responses in plants, including readjustment of transport and metabolic processes and growth inhibition in plants. As a result, the electron transport processes are impeded developing toxic systems. Several toxic reactive oxygen species (ROS) are generated in the cell wall region as well as inside the cell during the process, which affects membrane permeability, enzyme activity, metabolic pool, plant biomass, leaf chlorosis and necrosis [11], probably due to the conversion of arsenate to arsenite, a process that usually occurs in plants by synthesizing both enzymatic and non-enzymatic antioxidants. Arsenate acts as a phosphate analogue and is transported across the plasma membrane via phosphate transport systems. Inside the cytoplasm it reacts with phosphate, replacing ATP to form ADP-As, precisely because of disruption of energy flow in cells [12]. On the other hand, Bertolero et al. [13] reported that arsenate reduced to arsenite in plant tissue, does not normally have enough cytoplasmic concentrations to exert toxicity. Arsenite reacts with-SH group of enzymes and proteins due to suppression of cellular function and death [14]. The conversion of arsenate to arsenite, in vitro observation, is brought about by glutathione [15], with the concentration of high cellular plant tissues [16].

Curcumin (1, 7-bis(4-hydroxy-3-methoxyphenyl)-1,6-heptadiene-3,5-dione) is a polyphenol derived from the plant Curcuma longa. Extensive research over the last decades has indicated that curcumin exhibits anti-inflammatory, anti-oxidant, anti-viral and anti-infectious activities [17]-[19]. Curcumin such as other polyphenols is as strong anti-oxidant [20]. It significantly decreases lipid peroxidation, regulates antioxidant enzymes and scavenges hyperglycemia-induced reactive oxygen species (ROS), [21]. Oxidative stress and inflammation are closely associated with tumor growth, [22]. All such effect of curcumin has been reported from animal system and no work has been done on the role of curcumin in plant growth. The present investigation is an attempt to understand the role of curcumin in heavy metal stress amelioration in plant in general and arsenic stress amelioration in mung bean in particular.

\section{Materials and Methods}

Mung seeds [Vigna radiata (L.) Wilezek] viability was carried out by the floatation method. The seeds obtained from the market were put in a beaker of water and allowed to stand for five to ten minutes. Seeds that sank were considered viable. Required amount of viable mung seeds were taken and surface sterilized with $0.1 \% \mathrm{HgCl}_{2}$ solution for 3 - 5 minutes with successive shaking. After this, $\mathrm{HgCl}_{2}$ solution was thrown, washed thoroughly in tap water for 3 - 5 minutes, rinsed with distilled water for 2 - 3 times and decanted. Then the seeds were placed properly in petriplates containing moisten filter paper and germinated at $25^{\circ} \mathrm{C}$ for $2 \mathrm{~d}$. After two day of incubation the healthy germinated seeds with more or less equal height of shoots were transferred in the plastic cups $(150 \mathrm{ml})$ containing half strength Hoagland nutrient medium and were grown under light in growth chamber for 5 days. After every two days the medium was changed for healthy growth. On the 5th day from the day of transfer, the plants were treated with 0 , and $50 \mu \mathrm{M}$-cup was $50 \mu \mathrm{M}$, sodium arsenate solution. Each cup contains at least ten plants. In another set of treatments growing mung seedlings were subjected to different concentration of curcumin $(0 \mu \mathrm{M}, 25 \mu \mathrm{M}, 50 \mu \mathrm{M} \& 100 \mu \mathrm{M})$ and their interaction with $50 \mu \mathrm{M}$ sodium arsenate [(50 $\mu \mathrm{M}$ As +

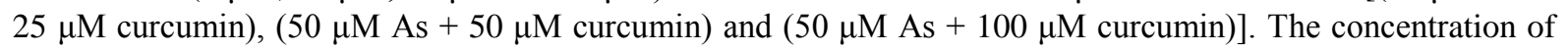
arsenic and curcumin used in this study was based on preliminary experiments. All these cups were kept under $16 \mathrm{~h} / 8 \mathrm{~h} \mathrm{light} /$ dark cycle in the growth chamber at $22^{\circ} \mathrm{C} \pm 3^{\circ} \mathrm{C}$. Plants were sampled after $48 \mathrm{~h}$ of teatments. The same treatments were used to test the effect of As, curcumin and their interaction at germination level. The viable mung seeds (25 in numbers) plated in petriplate containing water moistened filter is considered as control and in other set of treatments equal volume of treatment solution is used for germination of seeds. The appearance of the plumule at the filter paper surface was taken as germination. Germination percentage (\%) was recorded after $48 \mathrm{~h}$ of incubation. After $48 \mathrm{~h}$ of treatment growing mung seedlings were sampled and root and shoot length were measured using centimeter ruler and were separated into root and shoot and then oven dried at $80^{\circ} \mathrm{C}$ for $48 \mathrm{~h}$ to estimate the dry mass and expressed in g. plant ${ }^{-1}$. Root and shoot ratio was measured by dividing root 
length by shoot length.

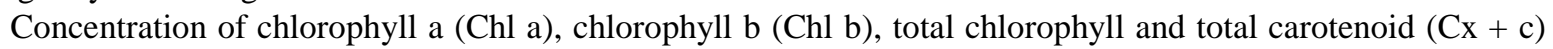
concentrations were analyzed following Shabala et al., [23] and Lichtenthaler [24] methods, respectively and expressed as $\mathrm{mg} \cdot \mathrm{g}^{-1} \mathrm{FW}$. About $50 \mathrm{mg}$ of leaf samples were placed in a glass vial, added with $5 \mathrm{ml}$ of $95.5 \%$ acetone, and the glass vials were sealed with parafilm to prevent evaporation and then stored at $4^{\circ} \mathrm{C}$ for $48 \mathrm{~h}$. The concentrations of $\mathrm{Chl} \mathrm{a,} \mathrm{Chl} \mathrm{b} \mathrm{and} \mathrm{Cx} \mathrm{+} \mathrm{c} \mathrm{were} \mathrm{measured} \mathrm{using} \mathrm{a} \mathrm{spectrophotometer} \mathrm{at} \mathrm{662,} 644$ and $470 \mathrm{~nm}$ respectively. A solution of $95.5 \%$ acetone was used as a blank. The Chl a, Chl b, total chlorophyll and carotenoid concentrations in the leaf tissues were calculated according to the following equations and expressed as $\mathrm{mg} \cdot \mathrm{g}^{-1}$ fresh mass:

$\mathrm{Chl} \mathrm{a}=9.784 \mathrm{D}_{662}-0.99 \mathrm{D}_{644}$.

$\mathrm{Chl} b=21.42 \mathrm{D}_{644}-4.65 \mathrm{D}_{662}$.

Total chlorophyll $=\mathrm{Chl} \mathrm{a}+\mathrm{Chl} b$.

$$
\mathrm{C}_{\mathrm{x}+\mathrm{c}}=\frac{1000 \mathrm{D}_{470}-1.90 \mathrm{Chl} \mathrm{a}-63.14 \mathrm{Chl} \mathrm{b}}{214}
$$

where $D_{i}$ is an optical density at the wavelength $i$.

\section{Statistical Analysis}

Each experiment was repeated thrice with each treatment sample containing ten individual plants and data presented are mean \pm standard error (SE). The results were subjected to one way ANOVA and LSD test was used for comparison between pairs of treatments. The data analysis was carried out using MS excel 2003 and statistical package, SPSS 10.

\section{Results and Discussion}

\subsection{Morphological Changes in Response to Arsenic and Curcumin Treatment}

The effect of arsenic on germination and growth of mung bean seedlings was in accordance with the earlier report [25]. Arsenic induced morphological, physiological, biochemical \& an anatomical change in plants is well known [25]. However, physiological, biochemical and anatomical changes occurs at the early stage of toxicity than the morphological changes. In the present study, arsenic induced morphological changes were least visible, but physiological and growth analysis showed growth reduction in mung bean seedling. Some of the plants under arsenic stress showed constriction of leaves with appearance of burning spots in the leaf apex. However, at the lower concentration of curcumin $(25 \mu \mathrm{M})$ better growth and ameliorating effect was evident by healthy growth of the mung bean seedlings when supplied alone or in combination with arsenic. Such effect of curcumin may be attributed to its antioxidant potential which protects cell from arsenic induced oxidative damage in mung bean. However, there is no report on the biological role of curcumin in plants.

\subsection{Effect of Arsenic and Its Interaction with Curcumin on Seed Germination}

The inhibitory effect of arsenic on the germination of mung seeds was evident from relatively lower germination rate (28\%) in arsenic treated seeds as compared to control (84\%) (Table 1). The germination percentage of curcumin treated seed was found to be $75 \%, 15 \%, 10 \%$ at 25,50 , \& $100 \mu \mathrm{M}$ treatment respectively. Seed germination percentage reduced under arsenic stress but curcumin at $25 \mu \mathrm{M}$ concentration showed protective effect on seed germination when treated alone or in combination with arsenic. The length of radicle growth also varied among the treatments as shown in Figure 1.

\subsection{Arsenic Induced Changes in Growth of Mung Bean Seedling}

An exposure to As $(50 \mu \mathrm{M})$ caused significant reduction in root and shoot length of mung bean seedlings (Figure 2). This inhibitory effect was more pronounced on root length than shoot length. The root length decreased by over $49.3 \%$ in response to $50 \mu \mathrm{M}$ As. In contrast the reduction in shoot length was comparatively lesser (15.13\%) which was also evident from declining root-shoot ratio upon As treatment (as depicted in Figure 3(B)). Further as compared to control root dry mass decreased by $75 \%$ whereas no significant changes in shoot dry 
Table 1. Effect of arsenic, curcumin and their interaction on Chl a, Chl b, Chl a:b, total Chlorophyll, total Carotenoid contents of growing seedings \& seed germination of mung bean [Vigna radiata (L.) Wilczek]. Data presented are mean \pm SE (n = 3). Mean value superscript with “a” \& "b" indicates significant mean difference from control \& arsenic treatment at p = 0.05 in multiple comparison test by LSD respectively.

\begin{tabular}{|c|c|c|c|c|c|c|}
\hline Treatments & $\begin{array}{c}\text { Chl a } \\
\left(\mathrm{mg} \cdot \mathrm{g}^{-1} \mathrm{FW}\right)\end{array}$ & $\begin{array}{c}\text { Chl b } \\
\left(\mathrm{mg} \cdot \mathrm{g}^{-1} \mathrm{FW}\right)\end{array}$ & $\begin{array}{l}\text { Chl a/Chl b } \\
\text { Ratio }\end{array}$ & $\begin{array}{l}\text { Total chlorophyll } \\
\left(\mathrm{mg} \cdot \mathrm{g}^{-1} \mathrm{FW}\right)\end{array}$ & $\begin{array}{l}\text { Total carotenoid } \\
\left(\mathrm{mg}^{-\mathrm{g}^{-1}} \mathrm{FW}\right)\end{array}$ & $\begin{array}{c}\text { Germination } \\
\%\end{array}$ \\
\hline Control & $6.59 \pm 0.05^{b}$ & $4.69 \pm 0.02^{b}$ & $1.41 \pm 0.005$ & $11.28 \pm 1.2^{\mathrm{b}}$ & $74.88 \pm 1.73^{\mathrm{b}}$ & $84.00 \pm 2.1^{\mathrm{b}}$ \\
\hline As $(50 \mathrm{mM})$ & $2.09 \pm 0.02^{\mathrm{a}}$ & $1.41 \pm 0.01^{\mathrm{a}}$ & $1.49 \pm 0.005^{\mathrm{a}}$ & $3.50 \pm 0.020^{\mathrm{a}}$ & $54.64 \pm 1.75^{\mathrm{a}}$ & $28.00 \pm 1.2^{\mathrm{a}}$ \\
\hline Cur (25 mM) & $5.46 \pm 0.05^{\mathrm{ab}}$ & $4.20 \pm 0.02^{\mathrm{b}}$ & $1.30 \pm 0.005^{\mathrm{b}}$ & $9.66 \pm 0.22^{\mathrm{b}}$ & $40.45 \pm 2.03^{\mathrm{ab}}$ & $75.00 \pm 1.2^{\mathrm{b}}$ \\
\hline Cur (50 mM) & $5.58 \pm 0.05^{\mathrm{b}}$ & $4.44 \pm 0.02^{\mathrm{b}}$ & $1.26 \pm 0.002^{\mathrm{ab}}$ & $10.01 \pm 1.31^{\mathrm{b}}$ & $57.29 \pm 1.73^{\mathrm{a}}$ & $55.00 \pm 0.2^{\mathrm{ab}}$ \\
\hline Cur (100 mM) & $5.83 \pm 0.05^{\mathrm{b}}$ & $3.93 \pm 0.02^{a b}$ & $1.48 \pm 0.002$ & $9.75 \pm 1.31^{a b}$ & $89.24 \pm 2.73^{b}$ & $50.00 \pm 0.2^{\mathrm{ab}}$ \\
\hline As + Cur $(50+25 \mathrm{mM})$ & $6.15 \pm 0.05^{\mathrm{b}}$ & $5.41 \pm 0.02^{\mathrm{b}}$ & $1.14 \pm 0.002^{\mathrm{ab}}$ & $11.55 \pm 1.31^{\mathrm{b}}$ & $95.21 \pm 1.73^{\mathrm{ab}}$ & $56.00 \pm 2.01^{\mathrm{ab}}$ \\
\hline As + Cur $(50+50 \mathrm{mM})$ & $5.49 \pm 0.05^{\mathrm{b}}$ & $5.26 \pm 0.05^{\mathrm{b}}$ & $1.04 \pm 0.002^{\mathrm{ab}}$ & $10.75 \pm 1.31^{\mathrm{b}}$ & $162.33 \pm 1.73^{\mathrm{ab}}$ & $37.03 \pm 2.03^{\mathrm{a}}$ \\
\hline As + Cur $(50+100 \mathrm{mM})$ & $6.66 \pm 0.05^{\mathrm{b}}$ & $4.65 \pm 0.02^{b}$ & $1.43 \pm 0.003$ & $11.31 \pm 1.31^{\mathrm{b}}$ & $72.75 \pm 1.73^{\mathrm{b}}$ & $38.33 \pm 2.14^{\mathrm{a}}$ \\
\hline
\end{tabular}

$50 \mu \mathrm{M}$ As+ $25 \mu \mathrm{M}$ Curcumin

$50 \mu \mathrm{M}$ As

Control
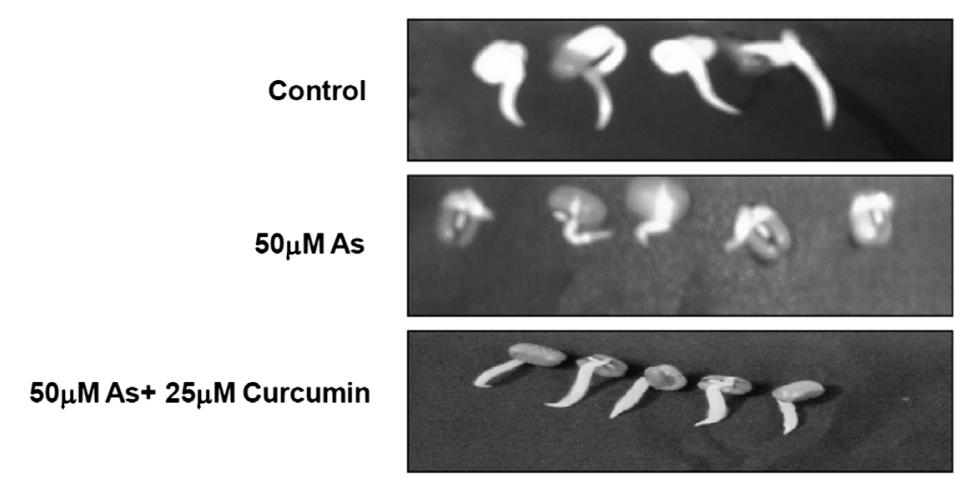

$50 \mu \mathrm{M}$ As $+50 \mu \mathrm{M}$ Curcumin

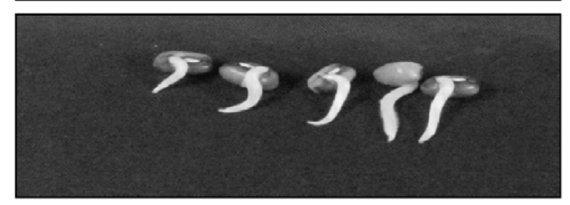

$50 \mu \mathrm{M}$ As $+100 \mu \mathrm{M}$ Curcumin

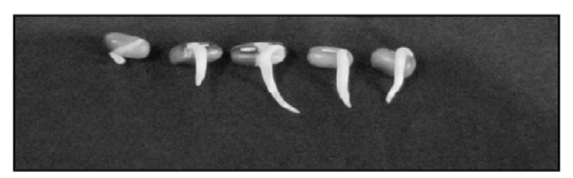

Figure 1. Effect of As and its interaction with Curcumin on germination of mung [Vigna radiata (L.) Wilczek] seeds.

mass was observed (Figure 4). However, the total dry mass of mung bean seedlings decreased by $24 \%$ in As treated seedlings as compared control. Azad et al. [26] also reported a decline in shoot length in Oryza sativa at higher concentration of arsenic. Arsenate in plants is absorbed and translocated through the phosphate channels [27] [28]. In our present study, the root growth was significantly inhibited than shoot growth. This may be attributed to the poor translocation of arsenate to the shoot due to the antagonistic effect of phosphate ions present in the nutrient solution on are senate for root to shoot translocation through the phosphate channels or the increased level of chelation of arsenate in the roots.

\subsection{Arsenic Induced Changes in Photosynthetic Pigments}

The results show that As also induces changes in photosynthetic pigment. In comparison to control, chl a, chl b, total chlorophyll and carotenoid content decrease by $68.25 \%, 69.98 \%$ and $27.03 \%$ respectively in shoot of 


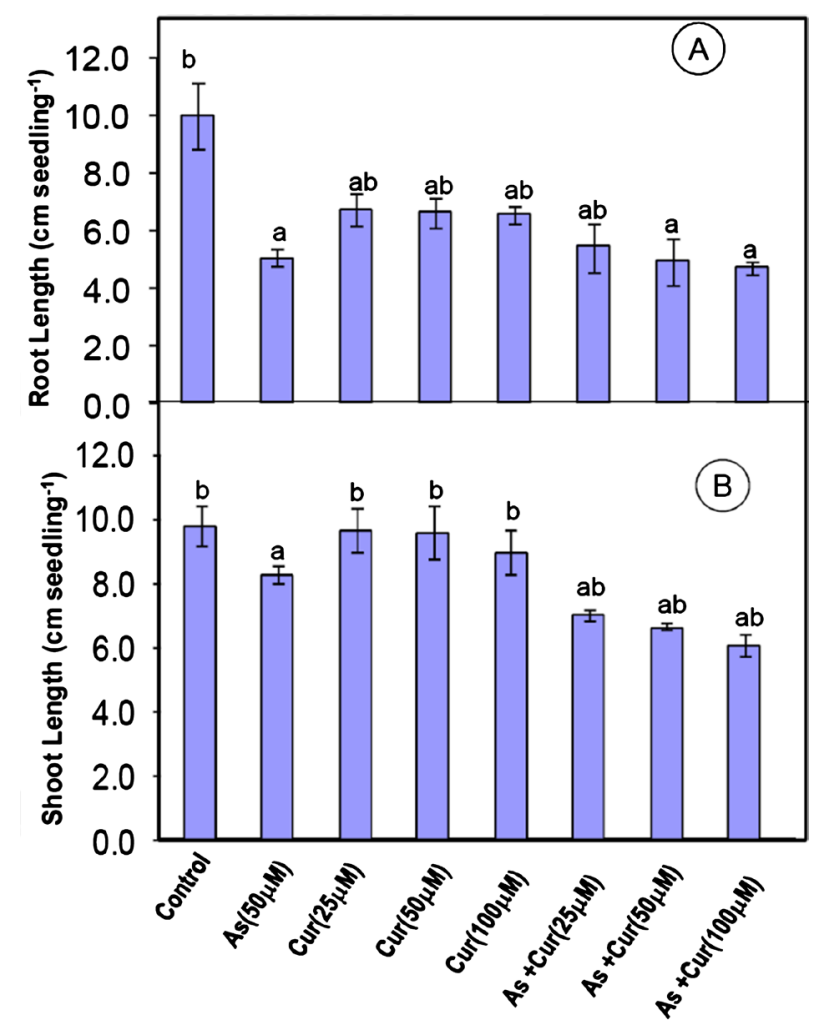

Figure 2. Effect of arsenic $(50 \mu \mathrm{M})$, curcumin $(25,50 \& 100 \mu \mathrm{M})$ and their interaction $[50 \mu \mathrm{M}$ As + curcumin $(25,50 \& 100$ $\mu \mathrm{M})$ ] on root (A) and shoot (B) length of growing seedlings of mung bean [Vigna radiata (L.) Wilczek]. Data presented are mean \pm SE $(n=3)$. Mean value superscript with “a” \& "b” indicates significant mean difference from control \& arsenic treatment at $\mathrm{p}=0.05$ in multiple comparison test by LSD respectively.

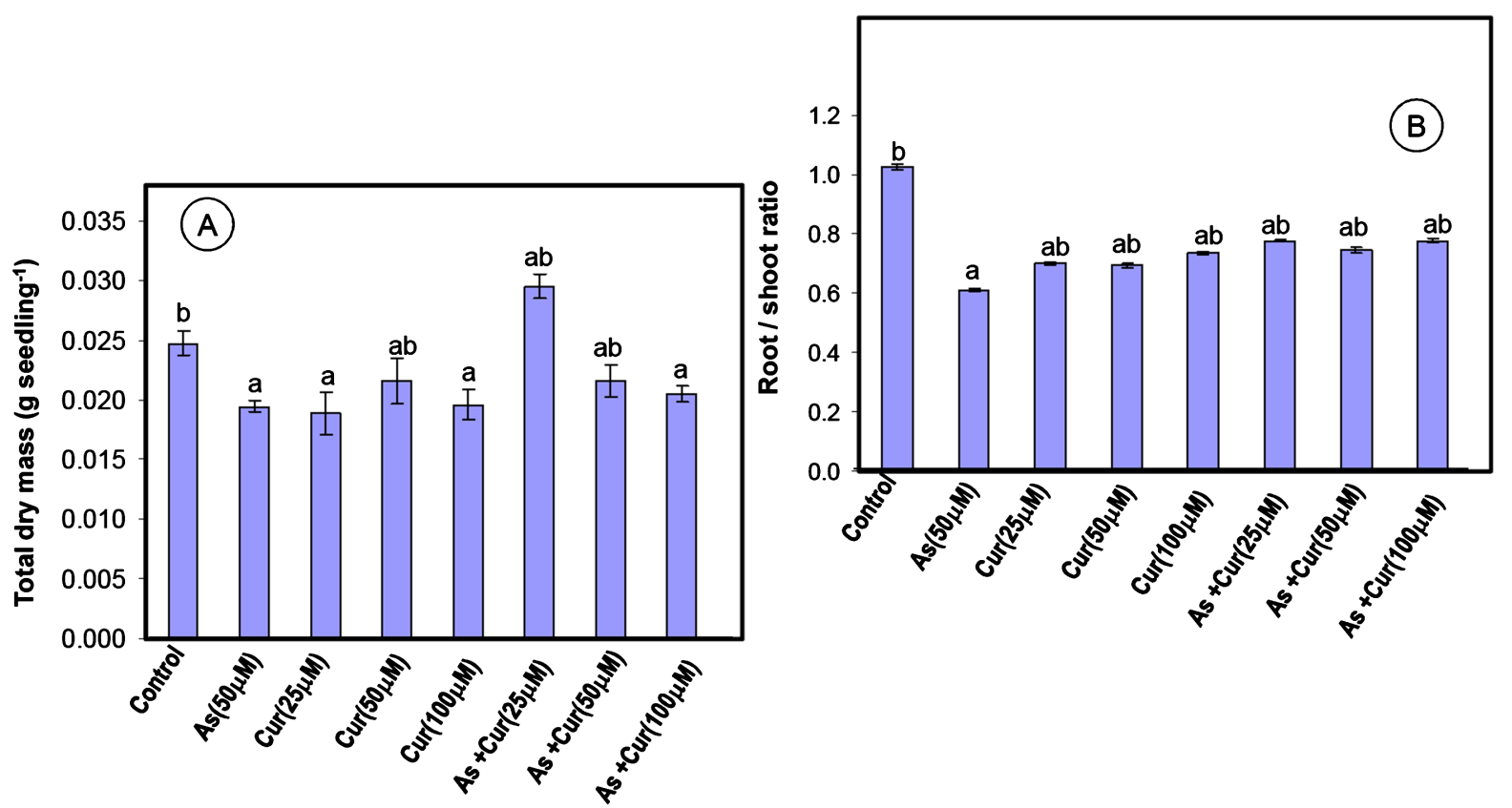

Figure 3. Effect of arsenic $(50 \mu \mathrm{M})$, curcumin $(25,50 \& 100 \mu \mathrm{M})$ and their interaction $[50 \mu \mathrm{M}$ As + curcumin $(25,50 \& 100$ $\mu \mathrm{M})$ ] on root (A) and shoot (B) dry mass of growing seedlings of mung bean [Vigna radiata (L.) Wilczek]. Data presented are mean \pm SE $(n=3)$. Mean value superscript with "a" \& "b" indicates significant mean difference from control \& arsenic treatment at $\mathrm{p}=0.05$ in multiple comparison test by LSD respectively. 


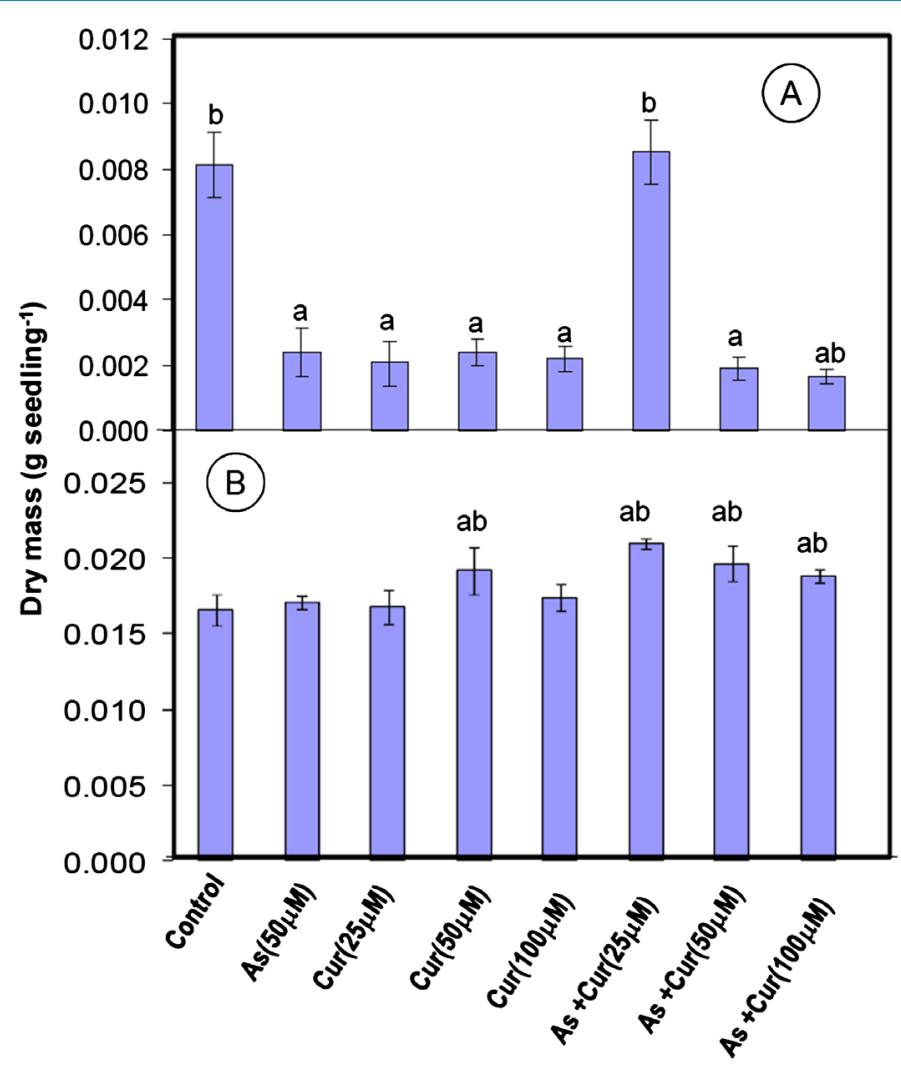

Figure 4. Effect of arsenic $(50 \mu \mathrm{M})$, curcumin $(25,50 \& 100 \mu \mathrm{M})$ and their interaction $[50 \mu \mathrm{M}$ As + curcumin $(25,50 \& 100 \mu \mathrm{M})]$ on $\operatorname{root}(\mathrm{A})$ and shoot (B) dry mass of growing seedlings of mung bean [Vigna radiata (L.) Wilczek]. Data presented are mean $\pm \mathrm{SE}(\mathrm{n}=3)$. Mean value superscript with "a" \& "b" indicates significant mean difference from control \& arsenic treatment at p $=0.05$ in multiple comparison test by LSD respectively.

growing mung seedlings. Chl a: Chl b ratio increased by $5.75 \%$ in arsenic treated mung seedlings. Srivastava et al. [29] also reported a similar decline of chl a, chl b content in Hydrilla verticillata at higher doses of arsenic treatment. This decrease in chlorophyll synthesis could be due to the generation of reactive oxygen species like superoxide and hydroxyl radicals, and hydrogen peroxide that have the potential to damage proteins, nucleic acids and amino acids involved in the biosynthetic pathway of chlorophyll synthesis [30].

\subsection{Effect of Curcumin and Its Interaction with As on Growth of Mung Bean Seeds}

Curcumin causes significant changes in growth of mung seedlings. Although changes in root length of mung bean is lower relative to control but compare to arsenic treated seedlings curcumin treated samples showed increase in root length. It was evident that As induced decrease in root growth is checked when curcumin and arsenic is treated simultaneously. There is no significant changes in shoot length in curcumin treated plants relative to control. But in comparison to arsenic treated sample, increase in shoot length due to curcumin treatment was observed. The interaction of curcumin with As however could not increase any shoot length. The root dry mass was decrease with curcumin treatment, but relative to control root dry mass shows no significant changes when $50 \mu \mathrm{M}$ As and $25 \mu \mathrm{M}$ curcumin are interacted. It also clearly indicates that the toxic effect of arsenic in root of growing mung seedlings is minimized by increasing root biomass over $350 \%$ when the plant is supplied with $50 \mu \mathrm{M}$ As along with $25 \mu \mathrm{M}$ curcumin. Although As have no significant effect on shoot biomass, curcumin increases shoot biomass by $11.64 \%$ at $50 \mu \mathrm{M}$ concentration relative to control. The interactive effect of arsenic with curcumin also showed increase in shoot biomass over $23.52 \%, 17.64 \%$ and $11.76 \%$ in arsenic treated plant at $25,50,100 \mu \mathrm{M}$ curcumin interaction respectively. Shoot dry mass increased because of curcumin interaction 
by $23.52 \%, 17.64 \%, 11.76 \%$ at $25,50,100 \mu \mathrm{M}$ curcumin concentration respectively with respect to arsenic treated plant. However the total dry mass increases by $20 \%$ in plants treated with arsenic and curcumin (50 $\mu \mathrm{M}$ As $+25 \mu \mathrm{M}$ curcumin) relative to control. It also clearly indicates that total dry mass has increased by $57.89 \%$ due to curcumin interaction ( $50 \mu \mathrm{M}$ As $+25 \mu \mathrm{M}$ curcumin) in comparison with As treated plants. This findings highlight the fact that curcumin prevents cell biomembranes damage. Lipid peroxidation is a chain reaction triggered by the free radicals produced in plants under stress conditions, leading to the damage of the cell membranes. Curcumin checks lipid peroxidation by scavenging the reactive free radicals that mediate the process of lipid peroxidation [31] [32]. Curcumin exhibits the free radical scavenging activity by donating H-atom from the phenolic group in acidic or neutral $\mathrm{p}^{\mathrm{H}}$ [33] [34].

\subsection{Effect of Curcumin and Its Interaction with As on Photosynthetic Pigments}

The interaction of curcumin with As shows changes in photosynthetic pigments. In comparison to control, chl a, chl b, total chlorophyll and carotenoid content decreased in shoot of growing mung seedlings as already mentioned. However in comparison with As treated plant, curcumin caused increase in chl a, chl b and apparently, total chlorophyll increased by $175.91 \%, 186.11 \%, 178.69 \%, 230.11 \%, 42.86 \% \& 26.77 \%$ in mung bean shoot at 25, $50 \& 100 \mu \mathrm{M}$ curcumin and its interaction with As (50 $\mu \mathrm{M}$ As $+25 \mu \mathrm{M}$ curcumin; $50 \mu \mathrm{M}$ As $+50 \mu \mathrm{M}$ curcumin \& $50 \mu \mathrm{M}$ As $+100 \mu \mathrm{M}$ curcumin) treatment respectively. The effect of curcumin and its interaction indicates that there was a decline in chlorophyll ratio highest being shown at $50 \mu \mathrm{M}$ As $+25 \mu \mathrm{M}$ curcumin treated mung seedlings. Total carotenoid content also increased due to curcumin interaction highest being shown by several thousand fold increase in mung seedlings treated with As \& curcumin (50 $\mu \mathrm{M}$ As $+50 \mu \mathrm{M}$ curcumin \& $50 \mu \mathrm{M}$ As $+100 \mu \mathrm{M}$ curcumin) respectively relative to only As treated plants. This increase in the total chlorophyll content can be attributed to the ability of curcumin to interact with DNA and mediate the transient increase in expression of enzymes of the C5 pathway for chlorophyll synthesis [35]. Such effect of curcumin may be due to its potentiality to act as antioxidant as reported elsewhere in animal cells [36]-[39].

The effect of arsenic on germination and growth of growing mung bean [Vigna radiata (L.) Wilezek] is found to be inhibitory, which is in consistent with earlier reports in mung bean [25] and in other plants. In the present study, reduction in root elongation was accompanied by decrease in shoot dry mass resulting into reduced growth in growing mung bean. Such reduction in growth may be due to anatomical changes in mung bean root as reported earlier [25]. We observe germination inhibition by arsenic in mung bean as well as the reduced growth in the growing seedlings. The inhibitory effect of arsenic was more pronounced in root than in shoot. Although, curcumin treatment did not induce seed germination at the level of the control plant when treated at different concentration $(25,50 \& 100 \mu \mathrm{M})$, the interactive effect of curcumin was interesting. The seed germination in curcumin and arsenic treated seed showed $56 \%, 37 \%, \& 38 \%$ relative to only arsenic treated seeds only with $28 \%$ at $25,50, \& 100 \mu \mathrm{M}$ curcumin. It clearly indicates that curcumin at lower concentration $(25 \mu \mathrm{M})$ can enhance germination in mung bean under arsenic stress. However, curcumin alone did not show significant increase in germination relative to control seed. Arsenic affects the plant by lowering the photosynthetic pigment content as reported in case of other stresses [40]-[45]. Pigment content and photosynthesis in various type of plant are generally reduced by arsenic and other metal stress. Chlorophyll a \& b decreased in the leaves of mung bean due to arsenic stresses, consequently lowering the total chlorophyll. Such decrease in chlorophyll many enhance chlorosis \& necrosis in plant as reported in case of other abiotic stresses. The reduction in carotenoid content due to arsenic stress may increase photosynthetic damage. However, total carotenoid is relatively higher than total chlorophyll which more prominently increased due to curcumin and its interaction with arsenic. Such increased carotenoid content may be an adaptive response to cope with stress induced photosynthetic damage.

\section{Conclusion}

From the present study, it may be suggested that the arsenic induced growth reduction in mung bean seedlings with simultaneous reduction in photosynthetic pigments but the curcumin, alleviates the adverse effect of arsenic on mung bean seedlings. It can also be suggested the arsenic induced germination inhibition of mung bean may be counteracted by curcumin at lower concentration. Further detail study on the curcumin effect on physiological events during mung seed germination and physiochemical and antioxidative responses of growing seedlings of mung bean (Vigna radiata) can reveal the exact mechanism underlying the amelioration of arsenic toxicity by curcumin in growing seedlings of mung bean (Vigna radiata). 


\section{Acknowledgements}

Authors gratefully acknowledge the Department of Biotechnology, Govt of India, for providing research support under the Biotech Hub (San. No.: BT/04/NE/2009 dated 21/09/2010) and Star College programs (San. No.: BT/ HRD/11/04/2011 dated 21/03/2011) to Karimganj College, Karimganj, Assam, India.

\section{References}

[1] Murphy, E.A. and Aucott, M. (1998) An Assessment of the Amounts of Arsenical Pesticides Used Historically in a Geographic Area. The Science of the Total Environment, 218, 89-101. http://dx.doi.org/10.1016/S0048-9697(98)00180-6

[2] Meharg, A.A. and Hartley-Whitaker, J. (2002) Arsenic Uptake and Metabolism in Arsenic Resistant and Nonresistant Plant Species. New Phytologist, 154, 29-43. http://dx.doi.org/10.1046/j.1469-8137.2002.00363.x

[3] Macnair, M.R. and Cumbes, Q. (1987) Evidence That Arsenic Tolerance in Holcus lanatus L. Is Caused by an Altered Phosphate Uptake System. New Phytologist, 107, 387-394. http://dx.doi.org/10.1111/j.1469-8137.1987.tb00190.x

[4] Meharg, A.A. and Macnair, M.R. (1991) The Mechanisms of Arsenate Tolerance in Deschampsia cespitosa (L.) Beauv and Agrostis capillaris L. New Phytologist, 119, 291-297. http://dx.doi.org/10.1111/j.1469-8137.1991.tb01033.x

[5] Paliouris, G. and Hutchinson, T.C. (1991) Arsenic, Cobalt and Nickel Tolerances in Two Populations of Silene vulgaris (Moench) Garcke from Ontario, Canada. New Phytologist, 117, 449-459. http://dx.doi.org/10.1111/j.1469-8137.1991.tb00009.x

[6] Carbonell-Barrachina, A.A., Burlo, F. and Mataix, J. (1995). Arsenic Uptake, Distribution and Accumulation in Tomato Plants: Effect of Arsenite on Plant Growth and Yield. Journal of Plant Nutrition, 18, 1237-1250. http://dx.doi.org/10.1080/01904169509364975

[7] Stoeva, N. and Bineva, T. (2003) Oxidative Changes and Photosynthesis in Oat Plants Grown in As-Contaminated Soil. Bulgarian Journal of Plant Physiology, 29, 87-95.

[8] Stoeva, N., Berova, M. and Zlatev, Z. (2005) Effect of Arsenic on Some Physiological Parameters in Bean Plants. Plant Biology, 49, 293-296. http://dx.doi.org/10.1007/s10535-005-3296-z

[9] Jha, A.B. and Dubey, R.S. (2004) Carbohydrate Metabolism in Growing Rice Seedlings under Arsenic Toxicity. Journal of Plant Physiology, 161, 867-872. http://dx.doi.org/10.1016/j.jplph.2004.01.004

[10] Hartley-Whitaker, J., Ainsworth, G. and Meharg, A. (2001) Copper- and Arsenic-Induced Oxidative Stress in Holcus lanatus L. Clones with Differential Sensitivity. Plant, Cell \& Environment, 24, 713-722. http://dx.doi.org/10.1046/j.0016-8025.2001.00721.x

[11] Nguyen, T., Sherratt, P.J., Huang, H.C., Yang, C.S. and Pickett, C.B. (2003) Increased Protein Stability as a Mechanism that Enhances Nrf2-Mediated Transcriptional Activation of the Antioxidant Response Element. Degradation of Nrf2 by the 26 S Proteasome. The Journal of Biological Chemistry, 278, 4536-4541. http://dx.doi.org/10.1074/jbc.M207293200

[12] Meharg, A. (1994) Integrated Tolerance Mechanisms-Constitutive and Adaptive Plant Responses to Elevated Metal Concentrations in the Environment. Plant, Cell Environment, 17, 989-993. http://dx.doi.org/10.1111/j.1365-3040.1994.tb02032.x

[13] Bertolero, F., Pozzi, G., Sabbioni, E. and Saffioffi, U. (1987) Cellular Uptake and Metabolic Reduction of Penta Valent to Trivalent Arsenic as Determinants of Cytotoxicity and Morphological Transformation. Carcinogenesis, 8, 803-808. http://dx.doi.org/10.1093/carcin/8.6.803

[14] Ullrich-Eberius, C.I., Sanz, A. and Novacky, A.J. (1989) Evaluation of Arsenate- and Vanadate-Associated Changes of Electrical Membrane Potential and Phosphate Transport in Lemna Gibba G1. Journal of Experimental Botany, 40, 119128. http://dx.doi.org/10.1093/jxb/40.1.119

[15] Delnomdedieu, M., Basti, M.M., Otvos, J.D. and Thomas, D.J. (1994) Reduction and Binding of Arsenate and Dimethylarsnate by Glutathione-A Magnetic Resonance Study. Chemico-Biological Interactions, 90, 139-155. http://dx.doi.org/10.1016/0009-2797(94)90099-X

[16] Alscher, R.G. (1989) Biosynthesis and Antioxidant Function of Glutathione in Plants. Physiologia Plantarum, 77, 457464. http://dx.doi.org/10.1111/j.1399-3054.1989.tb05667.x

[17] Joe, B., Vijaykumar, M. and Lokesh, B.R. (2004) Biological Properties of Curcumin Cellular and Molecular Mechanisms of Action. Critical Reviews in Food Science and Nutrition, 44, 97-111. http://dx.doi.org/10.1080/10408690490424702

[18] Goel, A., Kunnumakkara, A.B. and Aggarwal, B.B. (2008) Curcumin as “Curecumin”: From Kitchen to Clinic. Biochemical Pharmacology, 75, 787-809. http://dx.doi.org/10.1016/j.bcp.2007.08.016

[19] Sa, G, Das, T., Banerjee, S. and Chakraborty, J. (2010) Curcumin: From Exotic Spice to Modern Anticancer Drug. Al 
Ameen Journal of Medical Science, 3, 21-37.

[20] Kowluru, R.A. and Kanwar, M. (2007) Effects of Curcumin on Retinal Oxidative Stress and Inflammation in Diabetes. Nutrition \& Metabolism, 4, 8. http://dx.doi.org/10.1186/1743-7075-4-8

[21] Strasser,E.M., Wessner, B., Manhart, N., Roth, E. (2005) The Relationship between the Anti-Inflammatory Effects of Curcumin and Cellular Glutathione Content in Myelomonocytic Cells. Biochemical Pharmacology, 70, 552-559. http://dx.doi.org/10.1016/j.bcp.2005.05.030

[22] Biesalski, H.K. (2007) Polyphenols and Inflammation: Basic Interactions. Current Opinion in Clinical Nutrition and Metabolic Care, 10, 724-728. http://dx.doi.org/10.1097/MCO.0b013e3282f0cef2

[23] Shabala, S.N., Shabala, S.I., Martynenko, A.I., Babourina, O. and Newman, I.A. (1998) Salinity Effect on Bioelectric Activity, Growth, $\mathrm{Na}^{+}$Leaves: A Comparative Survey and Prospects for Screening. Australian Journal of Plant Physiology, 25, 609-616. http://dx.doi.org/10.1071/PP97146

[24] Lichtenthaler, H.K. (1987) Chlorophylls and Carotenoids: Pigments of Photosynthetic Biomembranes. Methods in Enzymology, 148, 350-380. http://dx.doi.org/10.1016/0076-6879(87)48036-1

[25] Singh, H.P., Batish, D.R., Kohli, R.K. and Arora, K. (2007) Arsenic Induced Root Growth Inihibition in Mung Bean Is Due to Oxidative Stress Resulting from Enhanced Lipid Peroxidation. Plant Growth Regulation, 53, 65-73.

[26] Azad, M.A.K., Mondal, A.H.M.F.K, Hossain, M.I. and Moniruzzaman, M. (2012) Effect of Arsenic Amended Irrigation Water on Growth and Yield of BR-11 Rice (Oryza sativa L.) Grown in Open Field Gangetic Soil Condition in Rajshahi. Journal of Environmental Science and Natural Resources, 5, 55-59. http://dx.doi.org/10.3329/jesnr.v5i1.11553

[27] Abedin, M.J., Feldmann, J. and Meharg, A.A. (2002) Uptake Kinetics of Arsenic Species in Rice Plants. Plant Physiology, 128, 1120-1128. http://dx.doi.org/10.1104/pp.010733

[28] Dhankher, O.P., Rosen, B.P., McKinney, E.C. and Meagher, R.B. (2006) Hyperaccumulation of Arsenic in the Shoots of Arabidopsis Silenced for Arsenate Reductase (ACR2). Proceedings of the National Academy of Sciences of the United States of America, 103, 5413-5418. http://dx.doi.org/10.1073/pnas.0509770102

[29] Srivastava,S., Srivastava, A.K., Singh, B., Suprasanna, P. and D’souza, S.F. (2013) The Effect of Arsenic on Pigment Composition and Photosynthesis in Hydrilla verticillata. Biologia Plantarum, 57, 385-389. http://dx.doi.org/10.1007/s10535-012-0288-7

[30] Dat, J., Vandenabeele, S., Iranova, E., Van Montagu, M., Inzé, D. and Van Breusegem, F. (2000) Dual Action of the Active Oxygen Species during Plant Stress Responses. Cellular and Molecular Life Sciences CMLS, 57, 779-795. http://dx.doi.org/10.1007/s000180050041

[31] Menon, V.P. and Sudheer Adluri, R. (2007) Antioxidant and Anti-Inflammatory Properties of Curcumin. Advances in Experimental Medicine and Biology, 595, 105-125. http://dx.doi.org/10.1007/978-0-387-46401-5_3

[32] Wright, J.S. (2002) Predicting the Antioxidant Activity of Curcumin and Curcuminoids. Journal of Molecular Structure: THEOCHEM, 591, 207-217. http://dx.doi.org/10.1016/S0166-1280(02)00242-7

[33] Barclay, L.R.C., Vinqvist, M.R., Mukai, K., Goto, H., Hashimoto, Y., Tokuanga, A. and Uno, H. (2000) The Antioxidant Mechanism of Curcumin: Classical Methods Are Needed to Determine Antioxidant Mechanism and Activity. Organic Letters, 2, 2841-2843. http://dx.doi.org/10.1021/ol000173t

[34] Priyadarsini, K.I., Maity, D.K., Naik, G.H., Kumar, M.S., Unnikrishnan, M.K., Satav, J.G. and Mohan, H. (2003) Role of Phenolic O:H and Methylene Hydrogen on the Free Radical Reaction and Antioxidant Activity of Curcumin. Free Radical Biology Medicine, 35, 475-484. http://dx.doi.org/10.1016/S0891-5849(03)00325-3

[35] Senthil, K. and Sarojini, R. (2009) Curcumin-DNA Interaction Studied by Fourier Transform Infrared Spectroscopy. International Journal of Biotechnology \& Biochemistry, 5, 251-259.

[36] Berger, A.C., Randak, P.A., Cahill, P.B., Choe, N., Canny, S., Wagner, C.A. and Geibel, I. (2002) Curcumin Pump Inhibitors Induce Functional Surface Expression of Detta F 508-CFTR Protein in Cystic Fibrosis Epithelial Cells. Nature Medicine, 8, 485-492. http://dx.doi.org/10.1038/nm0502-485

[37] Adams, B.K., Cai, J.Y., Armstrong. J., et al. ( 2005) EF24, a Novel Synthetic Curcumin Analog, Induces Apoptosis in Cancer Cells via a Redox-Dependent Mechanism. Anti-Cancer Drugs, 16, 263-275. http://dx.doi.org/10.1097/00001813-200503000-00005

[38] Bharat, B.A. (2007) Curcumin-Biological and Medical Properties. In: Ravindran, P.A., Babu, K.N. and Sivaraman, K., Eds., Turmeric: The Genus Curcuma: Medical and Aromatic Plants Industrial Profiles, CRC Press, Boca Raton, 297348.

[39] Banerjee, S.G., Bandyopadhyaya, K. and Chattopadhyay, B.D. (2010) Amelioration of Nicotine-Induced Damage of Blood Cells in Protein Malnourished Female Rats by Curcumin. International Journal of Pharmacology, 6, 444-455.

[40] Baszynski, T., Tukendorf, A., Ruszkowska, M., Skórzynska, E. and Maksymiec, W. (1988) Characteristics of the Photo- 
synthetic Apparatus of Copper Non-Tolerant Spinach Exposed to Excess Copper. Journal of Plant Physiology, 132, 708-713. http://dx.doi.org/10.1016/S0176-1617(88)80233-5

[41] Lidon, F.C. and Henriques, F.S. (1991) Limiting Step in Photosynthesis of Rice Plants Treated with Varying Copper Levels. Journal of Plant Physiology, 138, 115-118. http://dx.doi.org/10.1016/S0176-1617(11)80741-8

[42] Lidon, F.C. and Henriques, F.S. (1993) Changes in the Thylakoid Membrane Polypeptide Patterns Triggered by Excess $\mathrm{Cu}$ in Rice. Photosynthetica, 28, 109-117.

[43] Ciscato, M., Valcke, R., Van Loven, K., Clijsters, H. and Navari-Izzo, F. (1997) Effects of in Vivo Copper Treatment on the Photosynthetic Apparatus of Two Triticum Durum Cultivars with Different Stress Sensitivity. Physiologia Plantarum, 100, 901-908. http://dx.doi.org/10.1111/j.1399-3054.1997.tb00016.x

[44] Patsikka, E., Aro, E.M. and Tyystjarvi, E. (1998) Increase in the Quantum Yield of Photoinhibition Contributes to Copper Toxicity in Vivo. Plant Physiology, 117, 619-627. http://dx.doi.org/10.1104/pp.117.2.619

[45] Quartacci, M.F., Pinzino, C., Sgherri, C.L.M., Dalla, F.V. and Navari, F.I. (2000) Growth in Excess Copper Induces Changes in the Lipid Composition and Fluidity of PSII-Enriched Membranes in Wheat. Physiologia Plantarum, 108, 87-93. http://dx.doi.org/10.1034/j.1399-3054.2000.108001087.x 
Scientific Research Publishing (SCIRP) is one of the largest Open Access journal publishers. It is currently publishing more than 200 open access, online, peer-reviewed journals covering a wide range of academic disciplines. SCIRP serves the worldwide academic communities and contributes to the progress and application of science with its publication.

Other selected journals from SCIRP are listed as below. Submit your manuscript to us via either submit@scirp.org or Online Submission Portal.
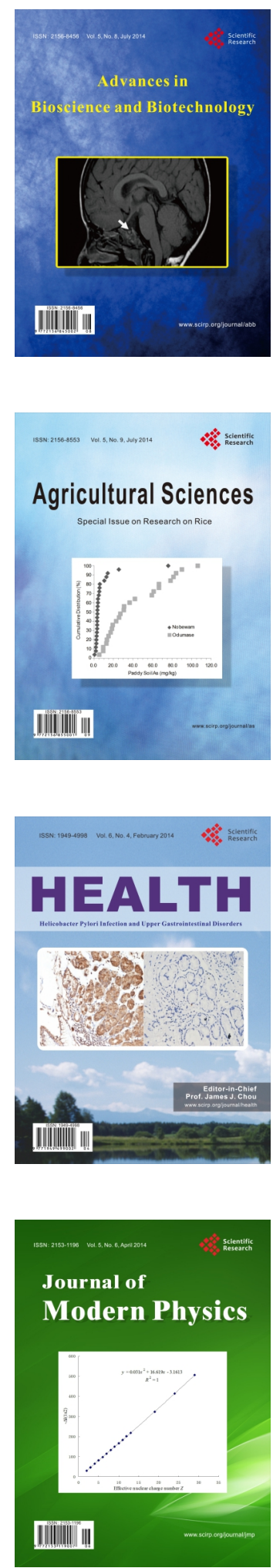
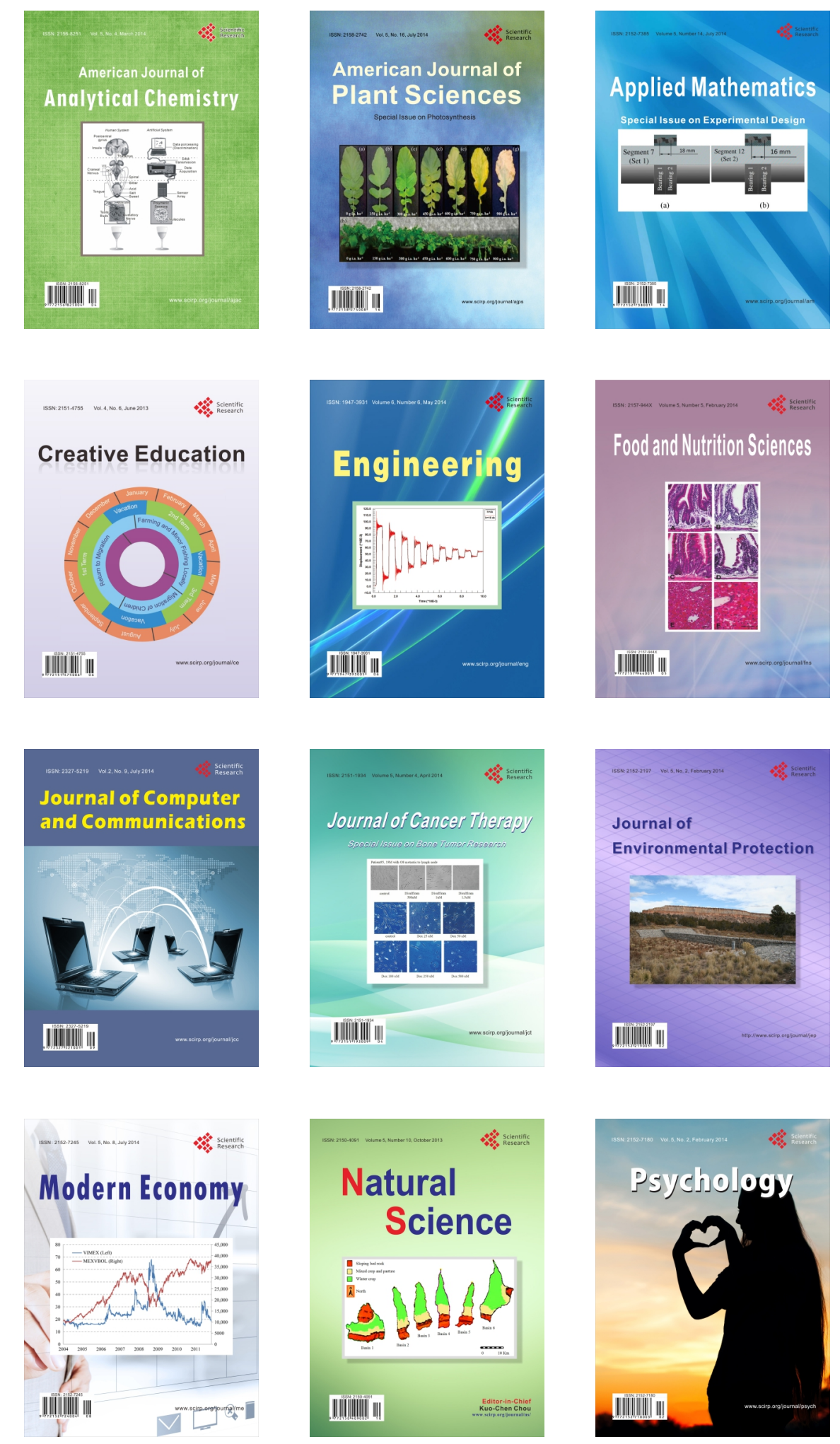